\title{
A Kiss Lajos-díj 2020. évi nyertese: dr. Bárth János
}

A Kiss Lajos-díj alapító okirata szerint a díj odaítélésére 2 vagy 3 évenként kerülhet sor. A díjat a kuratórium első ízben 2006-ban osztotta ki, s ezt követően 2 évenként ítélte oda. Az eddigi díjazottak időrendben a következők voltak: Tóth Valéria, Rácz Anita, Farkas Tamás, N. Fodor János, Slíz Mariann, Póczos Rita és Győrffy Erzsébet; közülük négyen a Debreceni Egyetem, hárman pedig az Eötvös Loránd Tudományegyetem oktatói.

A kuratórium 2020-ban arra az álláspontra jutott, hogy az elmúlt két év során a magyar történeti névkutatás általában is, és az egyes kutatói teljesítmények tekintetében is olyan jelentős eredményeket ért el, hogy ez a díj újbóli odaítélését ebben az évben minden tekintetben indokolttá teszi.

A kuratórium - mérlegelve a történeti névkutatásban az utóbbi években továbbra is örvendetesen megmutatkozó magas szintü teljesítményeket - egyhangú véleménnyel úgy döntött, hogy a Kiss Lajos-díjat 2020-ban az alábbi indokok alapján dr. Bárth Jánosnak, az Eötvös Loránd Tudományegyetem Magyar Nyelvtörténeti, Szociolingvisztikai, Dialektológiai Tanszéke adjunktusának ítéli oda.

Bárth János 1981-ben született Kalocsán. Középiskolai tanulmányait a kecskeméti Piarista Gimnáziumban végezte, majd az Eötvös Loránd Tudományegyetemen szerzett magyar nyelv és irodalom, valamint finn nyelv és kultúra szakon diplomát. 2005-ben az egyetem Nyelvtudományi Doktori Iskolájában a magyar nyelvészeti program (azon belül pedig a névtani alprogram) hallgatója lett. 2011-ben summa cum laude minősítéssel védte meg Székelyföldi történeti helynevek nyelvi elemzése: Névföldrajzi vizsgálatok Szabó T. Attila Erdélyi Helynévtörténeti Adattárában címmel a doktori értekezését, és szerzett általa PhD-fokozatot. 2010-ben tanársegéd lett a Magyar Nyelvtörténeti, Szociolingvisztikai, Dialektológiai Tanszéken, 2019-ben előléptették adjunktussá. A különböző egyetemi képzési formákban eddig közel húsz tantárgyat tanított, köztük jó néhány onomasztikai témájút is. Vendégelőadóként helynévtani kurzust tartott Finnországban, a Helsinki Egyetemen.

Bárth János kutatói pályája a magyar nyelvészet több területét is érinti, ezek azonban szorosan összefüggenek egymással: írásai nagyrészt a névtan (föként a helynévtan) tudományterületébe illeszkednek bele, részben pedig a dialektológiához kapcsolódnak, s e két diszciplína metszetében - mindegyik szempontrendszerét alkalmazva - helyezhetők el a névföldrajzi témájú munkái. Meghatározó, karakteres jellemzője a kutatásainak emellett az erdélyi és a székelyföldi tematika. Publikációs jegyzéke jelenleg 55 bibliográfiai tételt tartalmaz, írásai változatos, rangos fórumokon jelennek meg. Hazai és nemzetközi konferenciákon 42 alkalommal szerepelt előadással. Tudományos munkásságának hatását mutatja, hogy munkáira több mint 100 hivatkozást ismer.

Bárth János onomasztikai tárgyú kutatásaiban fontos irányvonalat képvisel a neves erdélyi névtudós, Szabó T. Attila helynévgyüjteményének a gondozása: a társszerkesztésében több térség (Erdély peremvidéke és Kolozs megye) helynévtára is megjelent, de a további kötetek munkálataiból is kivette a részét. Elindította az Erdélyi Helynévtörténeti Adattár és interaktív névföldrajzi atlasz (EHA) elnevezésü digitális adatbázist, amely mintegy 800000 kereshető, térképen megjeleníthető helynévi adatot tartalmaz Szabó T. 
Attila gyüjteményére támaszkodva (http://eha.elte.hu). E gyüjtemény integrálása a Magyar Nemzeti Helynévtár adatbázisába jelenleg zajlik. A leletmentés igénye is motiválta a háromszéki települések (Szotyor és Kilyén; Székföld; illetve Angyalos és Kökös) helyneveit és családneveit közreadó köteteket, amelyek megjelentetésében Bárth János sorozatszerkesztőként közremüködött. Az e témakörökhöz tartozó problematikát tanulmányok sorában dolgozta fel.

Bárth János kutatásai a névtudomány mellett a dialektológiához is sok szálon kapcsolódnak. Részt vett az Új magyar nyelvatlasz munkálataiban, többekkel együtt készített egy Beszélő atlaszt A magyar nyelvjárások atlasza ellenőrző gyüjtéséből, publikált több módszertani tanulmányt a nyelvi adatgyüjtésről, de az erdélyi történeti helynevek nyelvjárási sajátosságai is teret kaptak írásaiban. Meghatározó, alapító tagja az ELTE Geolingvisztikai mühelyének.

Onomasztikai és nyelvjárástörténeti kutatásainak sokirányú tapasztalata ötvöződik azon munkáiban, amelyekre a névföldrajzi megközelítés a jellemző, s amelyek a tudományos pályája utóbbi évtizedét leginkább meghatározzák. Tanulmányok egész sorát követően e részdiszciplína fontos új szintézissel is gazdagodott Bárth János jóvoltából: névföldrajzi vizsgálatainak eredményeit a 2018-ban közreadott Névföldrajzi térképlapok Erdélyből: A névadás területi variabilitása a történeti adatok tükrében címü monográfiájában összegezte.

Bárth János a tudományos ismeretterjesztésben is az élen jár azáltal, hogy jó néhány tudomány-népszerüsítő előadása mellett médiaszerepléseivel is népszerüsítette kedves tudományterületét: mintegy másfélszáz alkalommal szerepelt a Kossuth Rádió Hajnaltáj címü müsorában szótörténeti, nyelvjárási és helynevekkel kapcsolatos témákat érintve.

Bárth János tudományos tevékenységét 2018-ban Szabó T. Attila-díjjal ismerték el, és ugyanebben az évben három évre elnyerte a Magyar Tudományos Akadémia Bolyai János Kutatási Ösztöndíját is. Két alkalommal $(2018,2019)$ az ÚNKP Bolyai+ ösztöndíjat ugyancsak megkapta.

A fentieket figyelembe véve és mérlegelve a Kiss Lajos-díj kuratóriuma úgy döntött, hogy 2020-ban e tudományos díjat az eddigiekben végzett tudományos munkája elismeréseként dr. Bárth Jánosnak ítéli oda.

Debrecen, 2020. június 2.

\author{
Dr. Rácz Anita \\ a kuratórium elnöke
}
Dr. Hoffmann István
Dr. Tóth Valéria
Dr. Orosz László
Dr. Solymosi László
a kuratórium tagja
a kuratórium tagja
a kuratórium tagja
a kuratórium tagja

\title{
Anita Rácz, Winner of the 2020 Lajos Kiss Prize: Dr János Bárth
}

The Lajos Kiss Prize, awarded every two or three years since 2006, is considered to be a highly prestigious award for young onomasticians. The 2020 winner of the prize is Dr János Bárth, senior lecturer at the Institute of Hungarian Linguistics and Finno-Ugric Studies of Eötvös Loránd University, Budapest. He was given this award for his contribution to Hungarian Historical Onomastics, especially for his research on place names. 